\title{
Regulation of the prostaglandin enzymatic system by estradiol and progesterone in nonpregnant sheep cervix
}

\author{
Qi Zhang, Valta Collins ${ }^{1}$, Kaushik Chakrabarty ${ }^{1}$, James C Rose and Wen Xuan Wu \\ Department of Obstetrics and Gynecology and the Center of Research for Obstetrics and Gynecology, Wake Forest \\ University School of Medicine, Winston-Salem, North Carolina 27157, USA and ${ }^{1}$ The University of Oklahoma Health \\ Sciences Center, RP1, Suite 470, 800 N. Research park, Oklahoma City, Oklahoma 73104 USA
}

Correspondence should be addressed to $W \times W u$ at Department of Obstetrics and Gynecology, Wake Forest University Baptist Medical Center, Winston Salem, North Carolina 27157, USA; Email: wenwu@wfubmc.edu

\begin{abstract}
In the present study, we examined the in vivo effects of estradiol $\left(E_{2}\right)$ and progesterone on cyclooxygenase (COX) 2, prostaglandin F synthase (PTGFS, also known as PGFS), and membrane-associated prostaglandin E synthase 1 (mPTGES1) expression at both mRNA and protein levels using a nonpregnant ovariectomized (OVX) sheep model. Sixteen ewes were OVX shortly after ovulation. After 40 days, ewes were treated with saline (Cont, $n=5)$, or $E_{2}$ infused intravenously for 2 days $(50 \mu g / d a y, n=5)$ or intravaginal progesterone $(\mathrm{P})$ sponges for 10 days $(0.3 \mathrm{~g} \mathrm{P}, \mathrm{n}=6)$. Cervical COX2, PTGFS, and mPTGES1 mRNA and protein were quantified by northern and western blot analyses respectively. In situ hybridization and/or immunocytochemistry were used to localize the cellular distribution of COX2, PTGFS, and mPTGES1 mRNAs and proteins. COX2 mRNA abundance increased significantly in the cervix after $E_{2}$ treatment $(P<0.05)$. However, progesterone was a more potent stimulator than $E_{2}$ of $C O X 2$ mRNA and protein abundance in the cervix $(P<0.01)$. In contrast, PTGFS and $\mathrm{mPTGES1}$ mRNA and protein concentrations did not change after $E_{2}$ or progesterone treatment $(P>0.05)$. COX2, PTGFS, and $m$ PTGES1 mRNA and protein were only localized in cervical glandular epithelial cells. This study shows that increased cervical COX2 mRNA and protein, but not PTGFS and mPTGES1 mRNA and protein, were associated with $E_{2}$ and progesterone treatment in nonpregnant sheep. More strikingly, progesterone was a more potent stimulator of cervical COX2 expression than $E_{2}$. The expression of COX2, PTGFS, and mPTGES1 mRNA and/or protein was confined in the cervical glandular epithelial cells of nonpregnant sheep.

Reproduction (2007) 133 1027-1034
\end{abstract}

\section{Introduction}

The production of prostaglandins is largely regulated by prostaglandin cyclooxygenase (COX), and two types of the enzyme, COX1 and COX2, have been characterized in mammalian cells (Dewitt \& Smith 1988, Hla \& Neilson 1992, Otto \& Smith 1994). We have repeatedly shown that COX1 is constitutively expressed in pregnant and nonpregnant uterine tissues (Zhang et al. 1996, Wu et al. 1999). COX2 is an inducible enzyme that responds to inflammatory cytokines, growth factors (Diaz et al. 1992, Hempel et al. 1994), and steroid hormones (Wu et al. 1997 2004a, 2005b) and is increased in intrauterine tissues, including the cervix during premature and spontaneous term labor $(\mathrm{Wu}$ et al. 1999, 2004a, 2005a). Therefore, COX2 is the focal point of our present study. We have recently demonstrated that cervical glandular epithelial cells are the major cell type containing COX2 mRNA and protein in pregnant baboon and sheep (Wu et al. 2004b, 2005a). Our data suggest that the cervix is not only the target of prostaglandins but also a site for producing prostaglandins. However, the exact hormonal signals that regulate production and function of cervical prostaglandins are not understood.

In addition to COX, post-COX enzymes, such as prostaglandin $\mathrm{E}_{2}$ synthases (PTGES, also known as PGES) and prostaglandin $\mathrm{F}_{2 \alpha}$ synthase (PTGFS, also known as PGFS), determine the exact mix of two major prostaglandins involved in reproduction and parturition. PTGES acts downstream of COX to catalyze the conversion of $\mathrm{PGH}_{2}$ into $\mathrm{PGE}_{2}$ (Jakobsson et al. 1999, Watanabe et al. 1999). At least three forms of human PTGES have been cloned and characterized, including membrane-associated PTGES1 (mPTGES1) (Jakobsson et al. 1999), mPTGES2 (Tanikawa et al. 2002), and cytosolic PTGES (cPTGES; Tanioka et al. 2000). Among these, mPTGES1 shows coordinated induction with COX2 by inflammatory stimuli in various cells and tissues (Jakobsson et al. 1999, Murakami et al. 2002), 
including pregnant intrauterine tissues (Zhang et al. 2006), which, therefore, is the focus of the present study. PTGFS is responsible for converting $\mathrm{PGH}_{2}$ into $\mathrm{PGF}_{2 \alpha}$. Hence, information regarding the regulation of postCOX enzymes is also required for a better understanding of the control of the cervical prostaglandin production.

During pregnancy, the cervix grows ten times in length and ripens through the major part of gestation (Stevens \& Lowe 1992, Poma 1999). However, the biochemical mechanisms underlying the anatomic changes of the pregnant cervix are far from clear. In pregnant sheep and many other experimental animal models, progesterone is the major circulating hormone in maternal plasma throughout gestation and estradiol $\left(E_{2}\right)$ is not elevated until labor (Challis 1971, Liggins et al. 1973). In addition, $E_{2}$-induced premature labor prior to 0.9 gestation is often associated with cervical dystocia (Hindson et al. 1967, Liggins et al. 1973, Wu et al. 2004a). Based on these facts, we hypothesized that progesterone may be an important regulator of the cervical prostaglandin system. Indeed, additional progesterone priming prior to $E_{2}$ stimulation at 0.7 gestation optimized the expression of the cervical prostaglandin system induced by $E_{2}$ in pregnant sheep ( $\mathrm{Wu}$ et al. 2005a). However, it is impossible to determine the individual progesterone or $\mathrm{E}_{2}$ impact at the physiological level on regulation of the cervical prostaglandin enzymatic system in pregnant sheep because of the indispensable relationship between placental progesterone production and pregnancy maintenance. Therefore, in the present study, we used ovariectomized (OVX) nonpregnant sheep as a model to analyze the separate functions of progesterone and estrogen in regulating the cervical prostaglandin enzymatic system. In situ hybridization and immunocytochemical staining of COX, mPTGES1, and PTGFS were applied to determine the cell types which contained COX2, PTGFS, and mPTGES1 in the cervix.

\section{Materials and Methods}

\section{Animals and tissue collection}

Experimental procedures were approved by the Cornell University Institutional Animal Care and Use Committee. All facilities were approved by the American Association for the Accreditation of Laboratory Animal Care. In order to reduce endogenous ovarian steroid levels to a minimum, 16 nonpregnant ewes were OVX on the day of ovulation following the removal of progesterone sponges used to synchronize estrus. After 40 days, ewes were treated with one of the following regimens: saline controls (Cont, $n=5), \mathrm{E}_{2}$ infused intravenously for 2 days ( $50 \mu \mathrm{g} /$ day, $n=5)$, or intravaginal progesterone $(\mathrm{P})$ sponge for 10 days (containing $0.3 \mathrm{~g} \mathrm{P}, n=6$ ). Progesterone sponges were purchased from Carter Holt Harvey Plastic Products (Hamilton,
New Zealand) to produce plasma concentrations ranging from 1.5 to $2 \mathrm{ng} / \mathrm{ml}$ (data provided by the manufacturer). The dose of $E_{2}$ used produces physiological increments in plasma $\mathrm{E}_{2}$ concentrations, which stimulated uterine COX2 and estrogen receptor mRNA and protein expression (our pilot study, Wu et al. 1996, 1997). Two days of estrogen and ten days of progesterone treatment were chosen to simulate the physiological estrous cycle in vivo. All animals in the control group were infused with the same rate of physiological saline.

Tissues were removed while the ewes were under halothane general anesthesia. Cervix was rapidly dissected and divided into three portions (up, middle, and lower portions) and frozen in liquid nitrogen for later RNA and protein extractions. Middle portion of the cervix was used in the present study. Frozen tissues were stored at $-80{ }^{\circ} \mathrm{C}$ until extracted for RNA and proteins. Another similar portion of the cervix was slowly frozen in liquid nitrogen-cooled isopentane for later in situ hybridization and immunocytochemistry analysis.

\section{Polyadenylated RNA preparation and northern blot analysis}

Polyadenylated RNA was extracted from frozen cervix by oligo dT cellulose affinity chromatography using a commercial kit (Fast Track 2.0, Invitrogen). Samples of polyadenylated RNA ( $2 \mu \mathrm{g})$ were separated by electrophoresis on a $1.4 \%(\mathrm{wt} / \mathrm{vol})$ agarose- $0.66 \mathrm{M}$ formaldehyde gel and transferred onto a nylon membrane (NEN Life Science, Wilmington, DE, USA) and then subjected to northern blot analysis for COX2, mPTGES1, and PTGFS. Cyclophilin was used to control RNA loading.

\section{In situ hybridization}

Frozen sections ( $4 \mu \mathrm{m}$ thick) cut onto commercially prepared poly-L-lysine-coated slides (Sigma Chemical Company) were fixed in freshly prepared $4 \%$ paraformaldehyde in $0.1 \mathrm{M}$ phosphate buffer $(20 \mathrm{~min})$, washed twice in $0.1 \mathrm{M}$ phosphate buffer, immersed in triethanolamine- $\mathrm{HCl}$ (3.71 g triethylamide (TEA), $2 \mathrm{ml}$ of $6 \mathrm{M} \mathrm{NaOH}$, and $198 \mathrm{ml}$ water), $\mathrm{pH} 8.0$, and then TEA and acetic anhydride $(0.25 \%)$ for $10 \mathrm{~min}$. They were then washed in $2 \times$ SSC for $5 \mathrm{~min}$ and briefly in $70 \%$ ethanol and allowed to air-dry. The specimens were incubated for $2 \mathrm{~h}$ in a humidified container $\left(55^{\circ} \mathrm{C}\right)$ with $70 \mu \mathrm{l}$ prehybridization buffer $(50 \%$ freshly deionized formamide, $0.3 \mathrm{M} \mathrm{NaCl}, 20 \mathrm{mM}$ Tris- $\mathrm{HCl}(\mathrm{pH} 8.0)$, $5 \mathrm{mM}$ EDTA, $10 \mathrm{mM}$ sodium phosphate buffer $(\mathrm{pH} 8.0)$, and $1 \times$ Denhardt's solution), and for at least $16 \mathrm{~h}$ in hybridization buffer (i.e. prehybridization buffer plus probe $=1 \times 10^{6}$ c.p.m. per specimen in $70 \mu \mathrm{l}$ ). Control slides were hybridized with the labeled sense riboprobe. Slides were then washed thrice in $4 \times$ SSC and $4 \mathrm{mM}$ 
dithiothreitol (DTT, Sigma); thrice in NTE buffer (0.5 M $\mathrm{NaCl}, 10 \mathrm{mM}$ Tris- $\mathrm{HCl}$, and $5 \mathrm{mM}$ EDTA, $\mathrm{pH}$ 8.0) at $37^{\circ} \mathrm{C}$ (second NTE wash was for $30 \mathrm{~min}$ with $30 \mu \mathrm{g} / \mathrm{ml}$ RNase A (Sigma); $2 \times$ SSC and $1 \mathrm{mM} \mathrm{DTT;} 0.1 \times$ SSC and $1 \mathrm{mM}$ DTT at $60^{\circ} \mathrm{C}$; and finally $0.1 \times$ SSC at room temperature. The slides were then dehydrated in a graded series of ethanol plus $0.3 \mathrm{M}$ ammonium acetate. They were then dipped in emulsion (Kodak NTB2) and exposed for 1-4 weeks at $4{ }^{\circ} \mathrm{C}$. Following developing and fixing, they were counterstained with hematoxylin and eosin, mounted, and covered with a glass cover slip.

\section{Synthesis of probes}

Our cloned ovine COX2, mPTGES1, and PTGFS cDNAs in pCR II vector (Invitrogen), which include promoters for phage polymerases SP-6 to produce antisense probe and T-7 to produce sense probe, were linearized by appropriate restriction enzymes and antisense and sense riboprobes were synthesized using a commercial kit (MAXIscript, Ambion, Austin, TX, USA) labeled with $\left[\alpha_{-}^{32}\right.$ P]UTP for northern blot analysis or $\left[\alpha^{3}{ }^{35}\right.$ S]UTP for in situ hybridization (NEN Life Science). The plasmid containing cyclophilin cDNAs with RNA polymerase promoters was purchased from Ambion.

\section{Solubilized cell membrane extraction and western blot analysis}

Solubilized cell membrane extracts from cervix were prepared as described previously (Wu et al. 1999, 2004a). The protein concentration was determined by the method of Bradford (Bio-Rad Laboratories). The solubilized proteins $(100 \mu \mathrm{g} / \mathrm{lane})$ were then separated on $10 \%$ SDS-PAGE and electrophoretically transferred to the nylon membrane (Immobilon, Millipore Corp., Bedford, MA, USA), using a Bio-Rad transfer blot cell. Western blot analysis was performed as before (Wu et al. 1999, 2004a). The protein bands were visualized using an ECL Western Blotting Detection Kit (ECL, Amersham Life Sciences). Different lengths of X-ray exposure time were conducted to determine the linear range with the amount of mRNA and protein of cervical COX2, PTGFS, and mPTGES1. The molecular sizes of the proteins were determined by running standard molecular weight marker proteins (Bio-Rad Laboratories) in an adjacent lane. Chemiluminescence signals were analyzed and quantified with the scanner and data were analyzed with a densitometry program-Scan Analysis and quantified against an arbitrary scale in the plot.

\section{Immunocytolocalization for COX2, PTGFS, and mPTGES1}

Frozen sections $(4 \mu \mathrm{m})$ of ovine cervical tissues were immunostained for COX2, mPTGES1, and PTGFS using the avidin-biotin immunoperoxidase method. Unless otherwise specified, all slides were sequentially incubated for various times at room temperature with each of the following reagents: (1) $3 \%(\mathrm{v} / \mathrm{v}) \mathrm{H}_{2} \mathrm{O}_{2}$ in methanol for $30 \mathrm{~min}$ to block endogenous peroxidase activity; (2) 25\% (v/v) normal goat serum and $5 \%(\mathrm{w} / \mathrm{v})$ BSA in $0.05 \mathrm{M}$ Tris-Cl with $0.15 \mathrm{M} \mathrm{NaCl}(\mathrm{pH} 7.6)$ for $1 \mathrm{~h}$; (3) rabbit anti-human COX2 polyclonal serum or rabbit anti-bovine PTGFS, or rabbit anti-human mPTGES1 for $20 \mathrm{~h}$ at $4{ }^{\circ} \mathrm{C}$; (4) biotinylated goat antirabbit immunoglobulin G (IgG; Vector, Burlingame, CA, USA) for $0.5 \mathrm{~h}$; (5) avidin-biotin complex (Vector): $40 \mu \mathrm{l}$ each in $5 \mathrm{ml}$ of $0.05 \mathrm{M}$ Tris- $\mathrm{Cl}(\mathrm{pH} 7.6)$ for $0.5 \mathrm{~h}$; and 6) 3,3-diaminobenzidine tetrahydrochloride (DAB; Sigma) for $10 \mathrm{~min}$ : $4 \mu \mathrm{g} / 10 \mathrm{ml}$ of $0.05 \mathrm{M}$ Tris buffer ( $\mathrm{pH} 7.6$ ) to which was added $0.2 \mathrm{ml}$ of $3 \% \mathrm{H}_{2} \mathrm{O}_{2}$. After each incubation, the slides were washed with TBS for 15 min except for step (2). The slides were then counterstained with hematoxylin and mounted in Permount. Specificity of immunostaining for the enzymes was confirmed by three approaches: (1) omission of the primary antibody, (2) incubation of the slides with the normal rabbit serum instead of the primary antibodies, and (3) western blot analysis.

\section{Antibodies for COX2 and mPTGES1 and PTGFS used for western blot analysis}

A rabbit polyclonal antibody for COX2 raised against a synthetic peptide corresponding to a distinct C-terminal region of human COX2 (Oxford Biomedical Research Inc., Oxford, MI, USA) was used at 1:1000 dilution and incubated at $4{ }^{\circ} \mathrm{C}$ for $20 \mathrm{~h}$. The COX2 antibody used in the present study was able to bind a highly purified ovine COX2 (Oxford Biomedical Research; Cat. number: NP04) demonstrated in our previous study (Wu et al. 1997). A rabbit polyclonal antibody for human mPTGES1 (Cayman Chemical Com, Ann Arbor, MI, USA) was used at 1:500 dilution and incubated at $4{ }^{\circ} \mathrm{C}$ for $20 \mathrm{~h}$. A rabbit polyclonal antibody for bovine PTGFS kindly provided by Dr Watanabe (University of East Asia, Yamaguchi, Japan) was used at $1: 500$ dilution at $4{ }^{\circ} \mathrm{C}$ for $20 \mathrm{~h}$. The primary antibodies used for immunocytochemistry were the same antibodies used for western analysis. A rabbit polyclonal antibody for bovine $G \beta$ was purchased from Santa Cruz Biotechnology, Inc. (Santa Cruz, CA, USA). A second antibody, horseradish peroxidase-conjugated donkey anti-rabbit IgG, was used for western blot analysis (Amersham Life Sciences) and a biotinylated goat anti-rabbit IgG (Vector) was used for immunocytochemistry. The specificity of each antibody was determined by: (1) parallel analysis of the positive control protein; (2) preabsorbing antibody with synthetic polypeptides which were used for generating the antibody; and (3) incubating the blots with the normal rabbit serum instead of the antibody. 


\section{Statistical analysis}

Following normalization of the abundance of COX2, PTGFS, and mPTGES1 to cyclophilin (for northern) or G $\beta$ (for western) in individual samples, COX2, PTGFS, and mPTGES1 mRNA/protein concentrations in each western blot were expressed as a ratio of COX2, PTGFS, and mPTGES1 to cyclophilin or G $\beta$ respectively. One-way ANOVA was used to test for significant differences among the three groups (Cont, $\mathrm{E}_{2}$, and P) followed by multiple comparisons using the Tukey-Kramer procedure. Data were presented as means \pm S.E.M.

\section{Results}

\section{Regulation of COX2 $\mathrm{mRNA}$ and protein by $E_{2}$ and progesterone}

COX2 mRNA (Fig. 1) abundance increased significantly in the cervix after $\mathrm{E}_{2}$ treatment $(P<0.05)$. In contrast, cervical COX2 protein level was not induced in the present experimental system (Fig. 2). There was a significant increase in both COX2 mRNA and protein levels in the cervix after progesterone treatment. Progesterone was a more potent stimulator than $E_{2}$ of COX2 mRNA and protein abundance in the cervix $(P<0.01$, Figs 1 and 2).

\section{Regulation of PTGFS $m R N A$ and protein by $E_{2}$ and progesterone}

In contrast, PTGFS mRNA (Fig. 3) and protein (Fig. 4) concentrations did not change after $E_{2}$ or progesterone treatment $(P>0.05)$.

\section{Regulation of mPTGES1 $m R N A$ and protein by $E_{2}$ and progesterone}

Additionally, mPTGES1 mRNA (Fig. 3) and protein (Fig. 4) concentrations remained unchanged after $E_{2}$ or progesterone treatment $(P>0.05)$.

\section{In situ hybridization and immunohistochemistry analysis of COX2, PTGFS, and MPTGES1 mRNA and protein in the cervix}

Both COX2 mRNA (Fig. 5A) and protein (Fig. 5C) were only localized in cervical glandular epithelial cells. In addition, PTGFS mRNA (Fig. 5E) and protein (Fig. 5G) were also confined to the cervical glandular epithelial cells. mPTGES1 mRNA level was below the sensitivity of our in situ hybridization system; however, the protein of mPTGES1 was clearly present in the epithelial cells of the cervix (Fig. 5I). When the sense probes in the replacement of antisense probes, the hybridization signals for COX2 (Fig. 5B) and PTGFS (Fig. 5F) mRNA were abolished. Similarly, the brown immunostaining, produced by enzymatic conversion of diaminobenzadine substrate

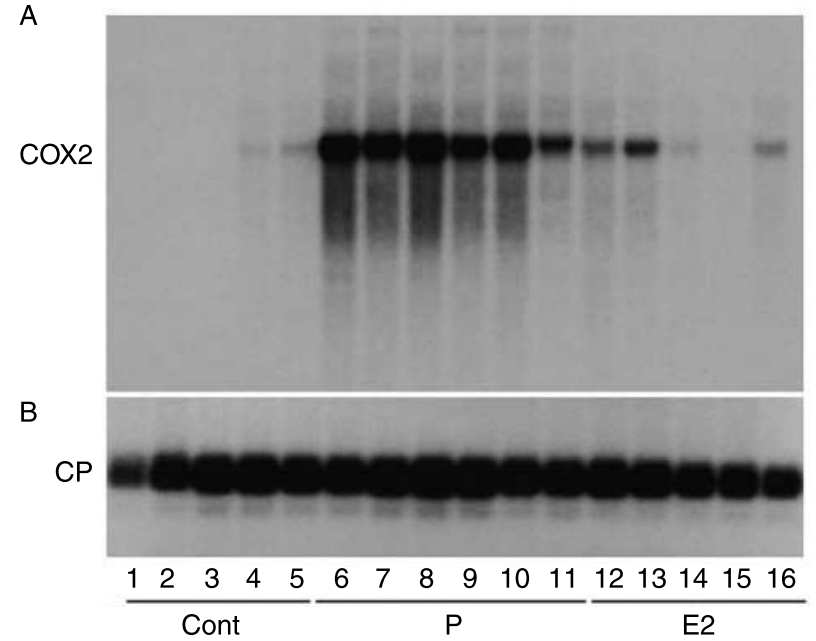

C

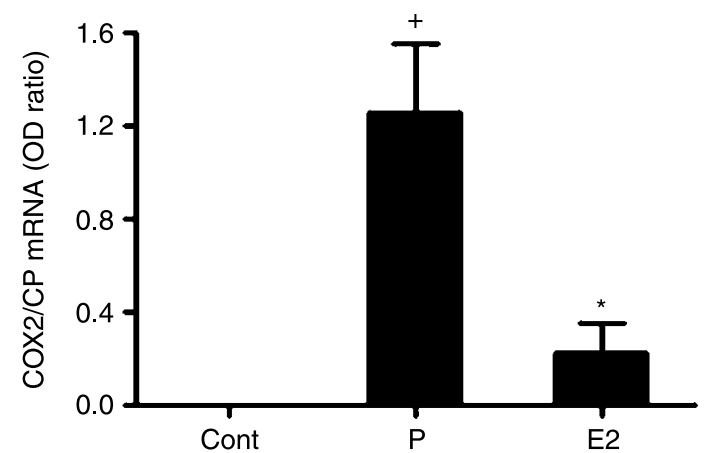

Figure 1 (A) COX2 mRNA in the cervix of OVX nonpregnant ewes: saline-treated controls (Cont, lanes $1-5)$, progesterone treated $(P$, lanes 6-11), and estradiol treated ( $E_{2}$, lanes $\left.12-16\right)$. Each lane represents one animal. (B) The same blot was hybridized with a cyclophilin (CP) CRNA probe to demonstrate relative amounts of RNA in each lane. (C) Northern blot signals for COX2 mRNA in the cervix of OVX nonpregnant ewes were quantified by densitometry and expressed as a ratio of COX2 to CP mRNA (mean \pm S.E.M., $n=5$ for $\mathrm{C}$ and $\mathrm{E}_{2}$ groups, $n=6$ for $\mathrm{P}$ group). COX $2 \mathrm{mRNA}$ was significantly increased $\left({ }^{*} P<0.05\right)$ in the cervix following $\mathrm{E}_{2}$ treatment compared with Cont group. $\mathrm{P}$ was a more potent stimulator of cervical COX2 mRNA expression than $\mathrm{E}_{2}\left({ }^{+} P<0.01\right.$ compared with Cont and $\left.\mathrm{E}_{2}\right)$.

into brown pigments, was absent when the primary antibodies for COX2, PTGFS, and mPTGES1 were replaced by normal rabbit serum (Fig. 5D, $\mathrm{H}$ and J).

\section{Discussion}

The present study is the first to simultaneously examine the regulatory effect of $\mathrm{E}_{2}$ and progesterone on COX2, PTGFS, and $\mathrm{mPTGES1}$ expression at both $\mathrm{mRNA}$ and protein levels in the cervix to provide a more complete picture on the control of the prostaglandin enzymatic system in the cervix by $E_{2}$ and progesterone. $E_{2}$ and progesterone are two major steroids during estrous cycle and throughout pregnancy which regulate the uterine growth and remodeling partly by controlling prostaglandins production and function. This is the first study to show that both $E_{2}$ and progesterone significantly elevated the abundance of cervical COX2, but 


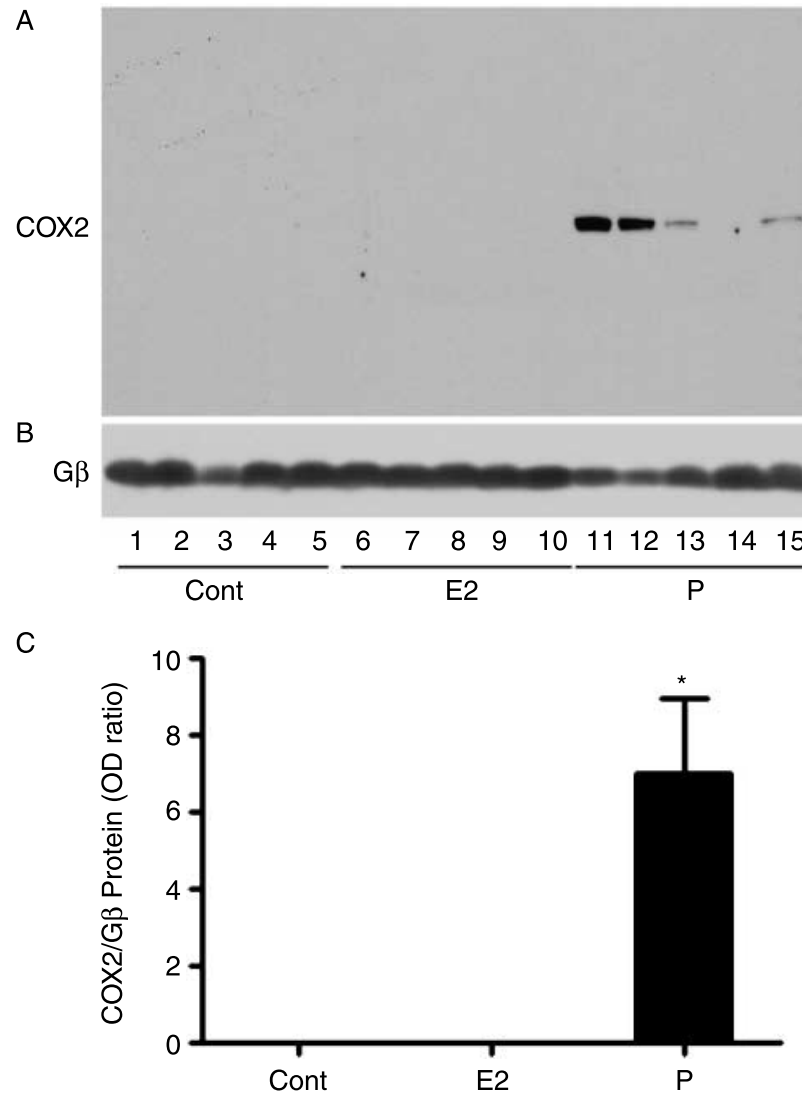

Figure 2 (A) Western blot analysis of COX2 protein in the cervix of OVX nonpregnant ewes: control saline-treated ewes (Cont, lanes 1-5), estradiol-treated ewes ( $E_{2}$, lanes $\left.6-10\right)$, and progesterone-treated ewes $(\mathrm{P}$, lanes 11-15). Each lane represents one animal. (B) Western blot signals for COX2 protein in the cervix of OVX nonpregnant ewes were quantified by densitometry (mean \pm s.E.M., $n=5$ for each group). COX2 protein was increased in the cervix following $\mathrm{P}$ treatment compared with Cont and $\mathrm{E}_{2}\left({ }^{*} P<0.01\right)$.

not PTGFS and mPTGES1, mRNA. Progesterone, but not $\mathrm{E}_{2}$, also stimulated COX2 expression at protein level. More strikingly, progesterone is a more powerful stimulator on cervical COX2 expression than $E_{2}$ at both mRNA and protein levels. Since prostaglandins are compounds with a very short half life, it is important to characterize local prostaglandin production capability. It has been very well documented, clinically and experimentally, that prostaglandins are effective agents in priming the cervix in several species including sheep (Aiken 1972, Novy et al. 1974, Owiny \& Fitzpatrick 1990, Sharma et al. 2005). Therefore, characterization of regulation of the key prostaglandin synthetic enzymes is required to provide a better understanding of the control of prelabor cervical ripening.

It is impossible to characterize the separate function of $E_{2}$ and progesterone on control of the cervical prostaglandin system during pregnancy due to the indispensable relationship between placental steroid production and pregnancy maintenance; thus, we conducted the present study using the nonpregnant sheep model. The control of the cervical prostaglandin system in

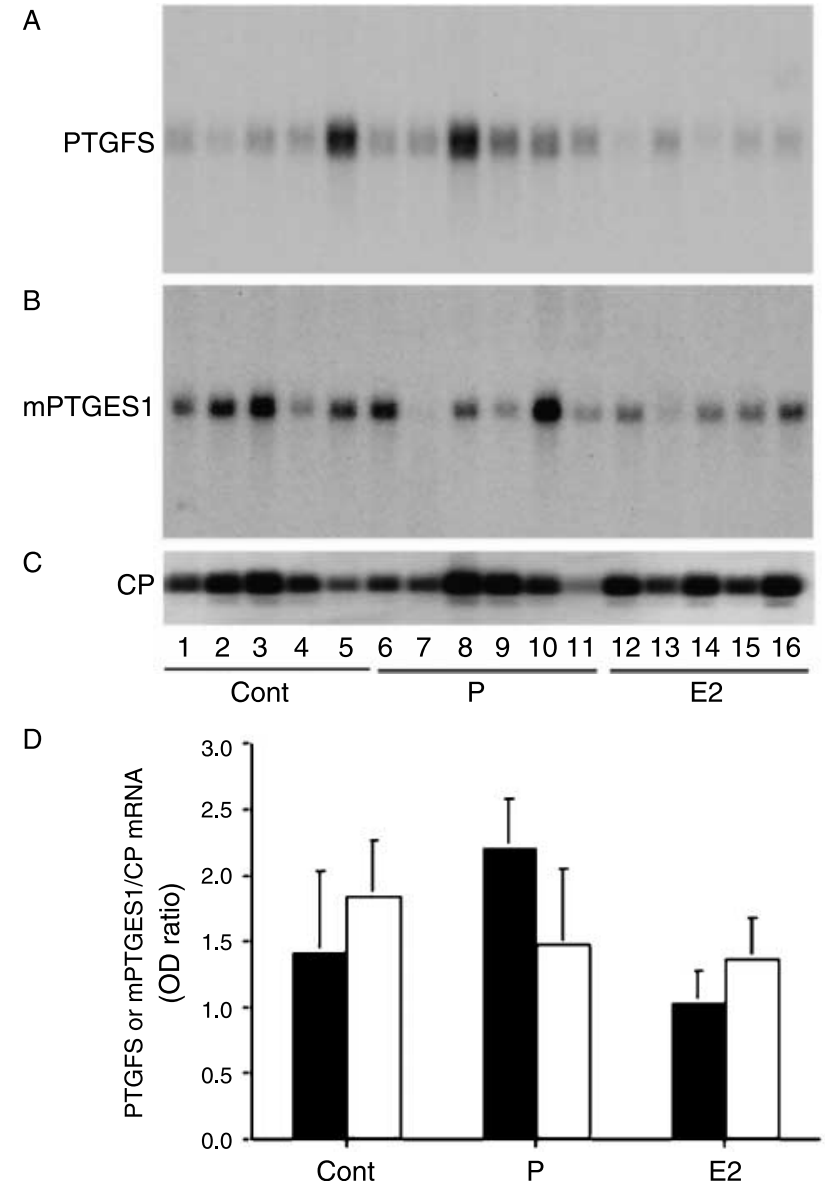

Figure 3 (A) PTGFS and (B) mPTGES1 mRNA in the cervix of OVX nonpregnant ewes: saline-treated controls (Cont, lanes 1-5), progesterone treated ( $P$, lanes $6-11)$, and estradiol treated $\left(E_{2}\right.$, lanes 12-16). Each lane represents one animal. (C) The same blot was hybridized with a cyclophilin (CP) cRNA probe to demonstrate relative amounts of RNA in each lane. (D) Northern blot signals for PTGFS and mPTGES1 mRNA in the cervix of OVX nonpregnant ewes were quantified by densitometry and expressed as a ratio of PTGFS (solid bar) and $\mathrm{mPTGES} 1$ (open bar) mRNA to $\mathrm{CP}$ (mean \pm S.E.M., $n=5$ for $\mathrm{C}$ and $\mathrm{E}_{2}$ groups, $n=6$ for $\mathrm{P}$ group). PTGFS and mPTGES1 mRNA remained unchanged after $E_{2}$ or $P$ treatment in the OVX nonpregnant sheep cervix $(P>0.05$, mean \pm S.E.M. $)$.

nonpregnant sheep model may not replicate the exact mechanisms which occur in pregnant sheep; however, it will certainly assist our understanding of the regulation of the pregnant cervical prostaglandin system. We have previously demonstrated that additional progesterone priming in pregnant sheep facilitated the cervical COX2 expression at both mRNA and protein levels (Wu et al. 2005a). Due to the presence of endogenously placentalproduced $E_{2}$ and progesterone, we were not able to define the separate function of $E_{2}$ or progesterone on the control of the cervical prostaglandin enzymatic system in a hormone-free system, which is the goal of the present study and is an extension of our previous publications. 

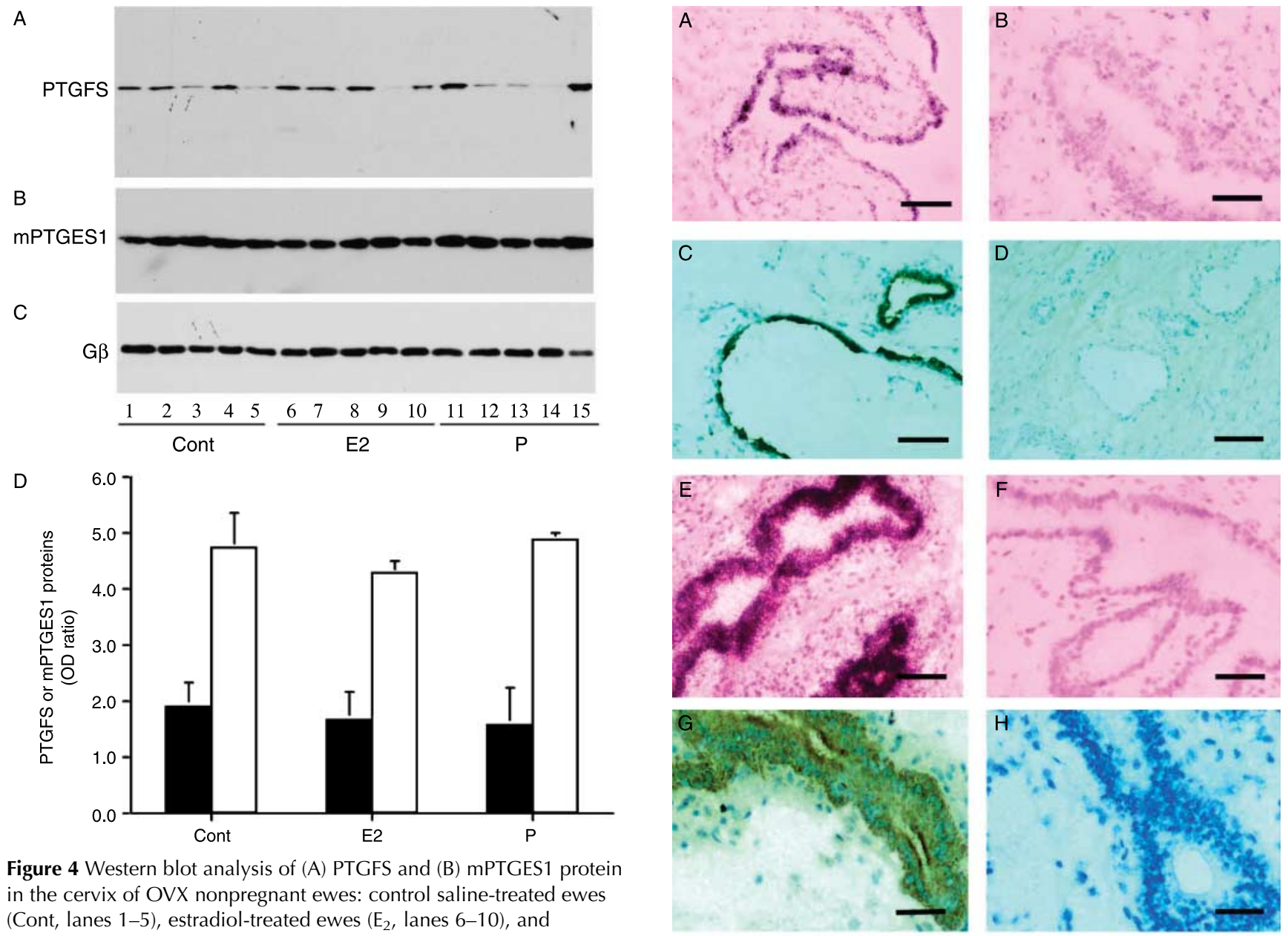

Figure 4 Western blot analysis of (A) PTGFS and (B) mPTGES1 protein in the cervix of OVX nonpregnant ewes: control saline-treated ewes (Cont, lanes 1-5), estradiol-treated ewes ( $E_{2}$, lanes 6-10), and progesterone-treated ewes ( $\mathrm{P}$, lanes 11-15). Each lane represents one animal. (C) G $\beta$ protein in each corresponding lane. (D) Western blot signals for the ratio of PTGFS (solid bar) and mPTGES1 (open bar) over $G \beta$ proteins in the cervix of OVX nonpregnant ewes were quantified by densitometry (mean \pm s.E.M., $n=5$ for each group). PTGFS and mPTGES1 proteins were unchanged in the cervix following $P$ and $E_{2}$ treatment.

Our present experiment provided direct evidence for progesterone's stimulation of the cervical COX2 expression at both mRNA and protein levels. Our observations strongly suggested that both $E_{2}$ and progesterone were the positive stimulators for cervical COX2 expression. The stimulating effect of progesterone on cervical COX2 was much more powerful than $E_{2}$ at both mRNA and protein levels. Interestingly, COX2 enzyme mRNA level was significantly elevated in the ovine cervix after $E_{2}$ treatment, although the level of COX2 protein was hardly detectable in the same tissue by western blot analysis. A potential explanation for the low COX2 enzyme protein expression after $\mathrm{E}_{2}$ treatment is that cervical COX2 may be controlled more strictly at the transcriptional level than at the translational level. Or the change of cervical COX2 protein was under the detection sensitivity of western analysis we used.
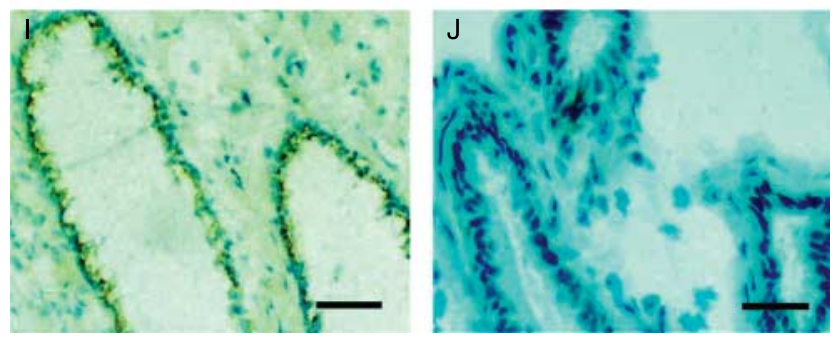

Figure 5 In situ and immunocytochemical analysis of cellular distribution of COX2, PTGFS, and mPTGES1 mRNA and protein in OVX nonpregnant sheep cervix. COX2 mRNA (A) and protein (C) were localized in epithelial cells of the cervical glands of the OVX nonpregnant sheep. Similarly, PTGFS mRNA (E) and protein (G) and mPTGES1 protein (I) were also confined to the cervical glandular epithelial cells. The specific in situ hybridization and immunostaining signals for COX2 (B), PTGFS (F) mRNA and COX2 (D), PTGFS (H) and mPTGES1(J) proteins were abolished when COX2 and PTGFS antisense riboprobes were replaced by sense riboprobes (B and $\mathrm{F}$ ) or in the absence of the primary PTGFS antibody $(\mathrm{D}, \mathrm{H}$, and $\mathrm{J})$ in the cervix. The black scale bar is $20 \mu \mathrm{m}$ except in $\mathrm{C}, \mathrm{E}, \mathrm{G}, \mathrm{H}$, and I in which it represents $40 \mu \mathrm{m}$.

Regulation of COX2 has been extensively studied. A series of COX2 inducers have been identified, e.g. cAMP (Wong etal. 1989), interleukin-1 (Kawaguchi et al. 1994), tumor necrosis factor (Diaz et al. 1992), transforming 
growth factor $\beta$ (Kester et al. 1994), phorbol ester (Habib et al. 1993), endothelin (Kester et al. 1994), and glucocorticoids (Whittle et al. 2000, Wu et al. 2001). Unfortunately, most studies have been conducted in in vitro cell culture systems. Such paradigms do not reflect the totality of events present in the intact structure of the tissue and in particular in vitro studies do not reflect local or blood-borne in vivo cell-to-cell communication. Therefore, they cannot completely reproduce the physiological response of the tissues as in vivo. A few studies have characterized in vivo regulation of COX2 in rat ovary (Sirois et al. 1992) by human chorionic gonadotropin and in nonpregnant and pregnant sheep uterus by $E_{2}$ and progesterone (Charpigny et al. 1997, Wu et al. 2004a, 2005a, 2005b). Results from our and others' previous studies demonstrated that progesterone could induce COX2 expression (Charpigny et al. 1997, Wu et al. 1997) and activated prostaglandin production (Louis et al. 1976) in nonpregnant and pregnant sheep uterus (Wu et al. 2005a). However, the regulation of cervical COX2, PTGFS, and mPTGES in vivo by progesterone and $\mathrm{E}_{2}$ has not been determined in any species.

It is very well documented that prostaglandin production is mainly controlled at COX2 level (Dewitt \& Smith 1988, Diaz et al. 1992, Hla \& Neilson 1992, Hempel et al. 1994); however, recent studies have suggested that post-COX enzymes may also determine the exact mix of the final prostaglandin product (Jakobsson et al. 1999, Murakami et al. 2002, Palliser et al. 2006). Therefore, parallel studies were performed to compare and contrast the changes of cervical COX2, mPTGES1, and PTGFS mRNA and protein in the same animals. In contrast to increased cervical COX2 levels after $E_{2}$ and progesterone treatment, the expression of PTGFS and mPTGES1 mRNA and protein levels were not significantly different in ewes that received $E_{2}$ or progesterone treatment compared with those of the control group, suggesting distinct regulatory roles of $E_{2}$ and progesterone on different prostaglandin enzymes. Cervical prostaglandin production in sheep is mainly controlled at COX level. Because of the central location of COX in the biosynthetic pathway of prostaglandins and the rapid catalytic inactivation of COX, this enzyme is a logical control point and a rate-limiting step in the formation of prostaglandins. In contrast to the stimulation of endometrial mPTGES1 by $E_{2}$ in pregnant sheep at 0.7 gestation (Zhang et al. 2006), there was no response of cervical mPTGES1 to $E_{2}$ in the present study, which provided another example of tissue-specific regulation of the prostaglandin enzymatic system. Palliser et al. (2006) have recently reported that there was no labor-associated induction of PTGFS in pregnant sheep cervix which also suggested that the labor associated rise of $E_{2}$ may not be able to stimulate cervical PTGFS expression. Consistent with Palliser's finding, we failed to induce the cervical PTGFS expression by $E_{2}$ in nonpregnant sheep.
Similar to the finding in pregnant sheep and baboon, COX2 mRNA and protein were both confined to the epithelial cells in nonpregnant sheep cervix. In addition, cervical PTGFS and mPTGES1 had a similar cellular distribution highlighting the importance of cervical epithelial cells in prostaglandin production. The junction between the cervix and the uterine body is the internal orifice of the cervix uteri, and at this point the nature of the epithelium and uterine wall changes. The endocervical canal runs between the uterine and vaginal cavities and is lined by a single layer of tall columnar mucussecreting epithelium that extends into the underlying stroma (endocervical mucus glands). These glandular structures are in fact deep slit-like invaginations of the surface epithelium, with blind-ended tubules (Stevens \& Lowe 1992). Thus, there is a large surface area for the production of cervical mucus, which fills the endocervical canal. To our surprise, it was this glandular structure that stained intensively for COX2, PTGFS, and mPTGES1 mRNA and/or protein. In contrast, cervical smooth muscle cells had almost negligible staining for all the three prostaglandin synthetic enzymes studied. By secreting mucus, cervical glandular cells can spread prostaglandins within the entire lower birth canal.

\section{Conclusion}

Increased cervical COX2 mRNA and protein, but not PTGFS and mPTGES1 mRNA and protein, were associated with $E_{2}$ and progesterone treatment in nonpregnant sheep. More strikingly, progesterone was a more potent stimulator of cervical COX2 expression than $\mathrm{E}_{2}$. The expression of COX2, PTGFS, and mPTGES1 mRNA and/or protein was all confined in the cervical glandular epithelial cells of nonpregnant sheep.

\section{Acknowledgements}

Supported by NIH HD 39247 and 21350. The authors declare that there is no conflict of interest that would prejudice the impartiality of this scientific work.

\section{References}

Aiken JW 1972 Aspirin and indomethacin prolong parturition in rats: evidence that prostaglandins contribute to expulsion of foetus. Nature 240 21-25.

Challis JRG 1971 Sharp increase in free circulating oestrogen in immediately before parturition in sheep. Nature 229208.

Charpigny G, Reinaud P, Tamby JP, Creminon C, Martal J, Maclouf J \& Gullomot M 1997 Expression of cyclooxygenase-1 and -2 in ovine endometrium during the estrous cycle and early pregnancy. Endocrinology 138 2163-2171.

Dewitt DL \& Smith WL 1988 Primary structure of prostaglandin G/H synthase from sheep vesicular gland determined from the complementary DNA sequence. PNAS 85 1412-1416.

Diaz A, Reginato AM \& Jimenez SA 1992 Alternative splicing of human prostaglandin $\mathrm{G} / \mathrm{H}$ synthase mRNA and evidence of differential 
regulation of the resulting transcripts by transforming growth factor $\beta 1$, interleukin $1 \beta$, and tumor necrosis factor $\alpha$. Journal of Biological Chemistry 267 10816-19822.

Habib A, Creminon C, Frobert Y, Grassi J, Pradelles P \& Maclouf J 1993 Demonstration of an inducible cyclooxygenase in human endothelial cells using antibodies raised against the carboxylterminal region of the cyclooxygenase-2. Journal of Biological Chemistry 268 23448-23454.

Hempel SL, Monick MM \& Hunninghake GW 1994 Lipopolysaccharide induces prostaglandin $\mathrm{H}$ synthase-2 protein and mRNA in human alveolar macrophages and blood monocytes. Journal of Clinical Investigation 93 391-396.

Hindson JC, Schofield BM \& Turner CB 1967 The effect of a single dose of stilboestrol on cervical dilatation in pregnant sheep. Research in Veterinary Science 8 353-360.

Hla T \& Neilson K 1992 Human cyclooxygenase-2 cDNA. PNAS 89 7384-7388.

Jakobsson PJ, Thoren S, Morgenstern R \& Samuelsson B 1999 Identification of human prostaglandin E synthase: a microsomal, glutathione-dependent, inducible enzyme, constituting a potential novel drug target. PNAS 96 7220-7225.

Kawaguchi H, Raisz LG, Voznesensky OS, Alander CB, Hakeda Y \& Pilbeam CC 1994 Regulation of the two prostaglandin G/H synthase by parathyroid hormone, interleukin-1, cortisol, and prostaglandin E2 in cultured neonatal mouse calvariae. Endocrinology 135 1157-1164.

Kester M, Coroneos E, Thomas PJ \& Dunn MJ 1994 Endothelin stimulates prostaglandin endoperoxide synthase- 2 mRNA expression and protein synthesis through a tyrosine kinase-signaling pathway in rat mesangial cells. Journal of Biological Chemistry 269 22574-22580.

Liggins GC, Fairclough RJ, Grieves SA, Kendall JZ \& Knox SJ 1973 The mechanism of initiation of parturition in the ewe. Recent Progress in Hormone Research 29 111-149.

Louis TM, Parry DM, Robinson JS, Thorburn GD \& Challis JRG 1976Effects of exogenous progesteroneand oestradiol on prostaglandin Fand 13,14dihydro-15-oxo prostaglandin F2 $\alpha$ concentrations in uteriand plasma of ovariectomized ewes. Journal of Endocrinology 73 427-439.

Murakami M, Nakatani Y, Tanioka T \& Kudo I 2002 Prostaglandin E synthase. Prostaglandins and Other Lipid Mediators 68 383-399.

Novy MJ, Cook MJ \& Manaugh L 1974 Indomethacin block of normal onset of parturition in primates. American Journal of Obstetrics and Gynecology 118 412-416.

Otto JC \& Smith WL 1994 The orientation of prostaglandin endoperoxide synthase- 1 and -2 in the endoplasmic reticulum. Journal of Biological Chemistry 269 19868-19875.

Owiny JR \& Fitzpatrick RJ 1990 Effect of intravaginal application of prostaglandin E2 gel on the mechanical properties of the ovine cervix uteri at term. American Journal of Obstetrics and Gynecology 163 657-660.

Palliser HK, Hirst JJ, Rice G, Ooi G, Dellios NL, Escalona RM \& Young IR 2006 Labor-associated regulation of prostaglandin E and $F$ synthesis and action in the ovine amnion and cervix. Journal of the Society for Gynecologic Investigation 13 19-24.

Poma PA 1999 Cervical ripening. Journal of Reproductive Medicine 44 657-668.

Sharma Y, Kumar S, Mittal S, Misra R \& Dadhwal V 2005 Evaluation of glyceryl trinitrate, misoprostol, and prostaglandin E2 gel for preinduction cervical ripening in term pregnancy. Journal of Obstetrics and Gynaecology Research 31 210-215.

Sirois J, Simmons DL \& Richards JS 1992 Hormonal regulation of messenger ribonucleic acid encoding a novel isoform of prostaglandin endoperoxide $\mathrm{H}$ synthase in rat preovulatory follicles. Induction in vivo and in vitro. Journal of Biological Chemistry 267 11586-11592.

Stevens A \& Lowe JS 1992 Female reproductive system. In Histology, pp 322-347. Eds A Stevens \& JS Lowe. London, New York: Gower Medical Publishing.
Tanikawa N, Ohmiya Y, Ohkubo H, Hashimoto K, Kojima M, Ito S \& Watanabe K 2002 Identification and characterization of a novel type of membrane-associated prostaglandin E synthase. Biochemical and Biophysical Research Communications 291 884-889.

Tanioka T, Nakatani Y, Semmyo N, Murakami M \& Kudo I 2000 Molecular identification of cytosolic prostaglandin E2 synthase that is functionally coupled with cyclooxygenase- 1 in immediate prostaglandin E2 biosynthesis. Journal of Biological Chemistry 275 32775-32782.

Watanabe K, Kurihara K \& Suzuki T 1999 Purification and characterization of membrane-bound prostaglandin E synthase form bovine heart. Biochimica et Biophysica Acta 1439 406-414.

Whittle WL, Holloway AC, Lye SJ, Gibb W \& Challis JRG 2000 Prostaglandin production at the onset of ovine parturition is regulated by both estrogen-independent and estrogen-dependent pathways. Endocrinology 141 3783-3791.

Wong WYL, Dewitt DL, Smith WL \& Richards JS 1989 Rapid induction of prostaglandin endoperoxide synthase in rat preovulatory follicles by luteinizing hormone and CAMP is blocked by inhibitor of transcription and translation. Molecular Endocrinology 3 1714-1723.

Wu WX, Owiny JR \& Nathanielsz PW 1996 Regulation of estrogen receptor mRNA and its peptide in the non-pregnant sheep uterus. Biology of Reproduction $\mathbf{5 5}$ 762-768.

Wu WX, Ma XH, Zhang Q, Owiny JR \& Nathanielsz PW 1997 Regulation of prostaglandin endoperoxide synthase 1 and 2 by estradiol in non-pregnant ovine myometrium and endometrium (in vivo). Endocrinology 138 4005-4012.

Wu WX, Ma XH \& Nathanielsz PW 1999 Tissue-specific ontogenic expression of prostaglandin $\mathrm{H}$ synthase 2 in the ovine myometrium, endometrium, and placenta during late gestation and at spontaneous term labor. American Journal of Obstetrics and Gynecology 181 $1512-1519$.

Wu WX, Ma XH, Unno N \& Nathanielsz PW 2001 In vivo evidence for stimulation of placental, myometrial, and endometrial prostaglandin $\mathrm{G} / \mathrm{H}$ synthase 2 by fetal cortisol replacement after fetal adrenalectomy. Endocrinology 142 3857-3864.

Wu WX, Ma XH, Coksaygan T, Chakrabarty K, Collins V, Rose JR \& Nathanielsz PW 2004a Prostaglandin mediates premature delivery in pregnant sheep induced by estradiol at 121 days of gestational age. Endocrinology 145 1444-1452.

Wu WX, Smith GCS, Rose J \& Nathanielsz PW 2004b Characterization of the concentration gradient of prostaglandin $\mathrm{H}$ synthase 2 mRNA throughout the pregnant baboon uterus. Journal of Endocrinology 182 241-248.

Wu WX, Coksaygan T, Chakrabarty K, Collins V, Rose JR \& Nathanielsz PW 2005a Sufficient progesterone-priming prior to estradiol-stimulation is required for optimal induction of the cervical prostaglandin system. Biology of Reproduction 73 343-350.

Wu WX, Wolf R, Chakrabarty K, Collins V, Valentine B, Unno N, Sheikh A, Nathanielsz PW \& Rose JR 2005b Induction of intrauterine prostaglandin $\mathrm{H}$ synthase 2 by estradiol after fetal adrenalectomy. Endocrine 26 153-159.

Zhang Q, Wu WX, Brenna JT \& Nathanielsz PW 1996 Increased expression of CPLA2 and PGHS-2 in ovine endometrium and myometrium during glucocorticoid induced premature labor and spontaneous labor. Endocrinology 137 4010-4017.

Zhang Q, Collins V, Chakrabarty K, Wolf RF, Unno N, Howe D, Rose JC \& Wu WX 2006 Regulation of membrane-associated prostaglandin E2 synthase 1 in pregnant sheep intrauterine tissues by glucocorticoid and estradiol. Endocrinology 147 3719-3726.

Received 15 November 2006

First decision 4 January 2007

Accepted 23 January 2007 